\title{
High summer abundances of small pelagic copepods at the Antarctic Polar Front-implications for ecosystem dynamics
}

\author{
C.D. Dubischar ${ }^{\mathrm{a}, *}$, R.M. Lopes ${ }^{\mathrm{b}}$, U.V. Bathmann ${ }^{\mathrm{a}}$ \\ a Alfred-Wegener-Institut für Polar- und Meeresforschung (AWI), Am Handelshafen 12, D-27515 Bremerhaven, Germany \\ ${ }^{\mathrm{b}}$ Universidade Estadual de Santa Cruz, Depto Ciências Biológicas, Ilhéus, Brazil
}

Received 15 December 1999; received in revised form 15 August 2000; accepted 6 September 2000

\begin{abstract}
Within the framework of the SO-JGOFS, we investigated the distribution of small copepods $(<2.0 \mathrm{~mm})$ in relation to the hydrography of the Antarctic Polar Front during summer 1995/96. The community of small copepods was dominated by Oithona similis, followed by Oithona frigida and Ctenocalanus citer. The total abundance of these copepods was extremely high throughout the study area, with peaks of up to 49,000 ind. $\mathrm{m}^{-3}$, to which naupliar and early copepodid stages (CI-CIII) contributed a high percentage. The accumulation of such a high standing-stock of small copepods is probably related to retention mechanisms provided by the meandering structure of the frontal system and to the biology of the dominant species Oithona similis, Oithona frigida, and Ctenocalanus citer.

Stage distribution and metabolic demand of the dominant species indicate a very active and productive zooplankton community, with high grazing pressure on smaller plankton particles and faecal material, leading to high recycling efficiencies and low export rates due to sinking material. This study gives further support to recent findings that small copepod species and early developmental stages of all species are key components of the plankton food web of the Southern Ocean. (C) 2002 Elsevier Science Ltd. All rights reserved.
\end{abstract}

\section{Introduction}

Early investigations on the biology and ecology of Antarctic zooplankton dealt mainly with animals collected by coarse $(>200 \mu \mathrm{m})$ plankton nets (e.g., Hardy and Gunther, 1935; Foxton, 1956; Voronina, 1968; Yamanaka, 1976). This has led to the longstanding view that large copepod species, euphausiids, and salps dominate summer zooplankton assemblages in the Southern Ocean

\footnotetext{
*Corresponding author: Tel.: +49-471-4831-1811; fax: +49471-4831-425.

E-mail address: cdubischar@awi-bremerhaven.de (C.D. Dubischar).
}

(Conover and Huntley, 1991; Smith and SchnackSchiel, 1990). As a result, our knowledge on the distribution and life-cycle strategies of Antarctic copepods has been strongly biased towards largesized species (e.g., Bathmann et al., 1993; Marin, 1988; Schnack-Schiel and Hagen, 1995).

The increasing use of finer plankton nets $(55-200 \mu \mathrm{m})$ since the mid-1980s has provided a more realistic view of the ecological significance of small copepods such as Oithona, Oncaea, and clausocalanids (Atkinson, 1998; Chojnacki and Weglenska, 1984; Foster, 1987; Fransz, 1988; Schnack-Schiel and Mizdalski, 1994; Zmijewska, 1988). Copepod abundances of up to 8000 ind. $\mathrm{m}^{-3}$ and average zooplankton biomass 
of 1-2 $\mathrm{g} \mathrm{C} \mathrm{m}^{-2}$ have been recorded since then for the upper mixed layer of Antarctic and Subantarctic waters (Atkinson, 1996; Fransz and Gonzalez, 1997; Metz, 1995, 1996). Therefore, small copepods are undoubtedly more abundant than their larger counterparts, and their population biomass has been proposed to equal that of large calanoids (Metz, 1996).

More recently it has been reported that zooplankton biomass at the Antarctic Polar Front (APF) may reach up to $11 \mathrm{~g} \mathrm{C} \mathrm{m}^{-2}$, according to estimates obtained from a towed optical plankton counter (OPC) during austral summer 1995/96 (Read et al., 2002). Although a calibration exercise has suggested that the OPC overestimates copepod biomass by a factor of $\sim 1.7$ (Pollard et al., 2002), it is now fully recognized that planktonic animals smaller than $2.0 \mathrm{~mm}$ are at least one to two orders of magnitude more abundant at the APF during summer than previously believed. Hence, additional information is needed on the species-specific and ontogenetical distribution of small metazooplankton for a better understanding of food web interactions at the APF.

The Atlantic sector of the APF has been identified by the joint global ocean flux study (JGOFS) as one of the major sub-systems of the Southern Ocean exhibiting high phyto- and zooplankton production and possibly high export of pelagic material to the ocean floor, as compared to the surrounding open waters (Smetacek et al., 1997). Recent information obtained by the SeaWIFS satellite (http://seawifs.gsfc.nasa.gov/seawifs.html; A. Belem, AWI, pers. commun.) indicates that the APF is characterized by high pigment concentrations (i.e. high surface phytoplankton biomass) that are closely associated to the hydrographical structure of the meandering front (Bathmann et al., 1997). Such meanders and eddies may segregate different phytoplankton blooms within a few kilometers (Bathmann et al., 1997). Although evidence exists that frontal systems play a major role in macrozooplankton dynamics in the Southern Ocean (Huntley and Niller, 1995; Smith and Schnack-Schiel, 1990), the spatial distribution of small $(<2.0 \mathrm{~mm})$ Antarctic and Subantarctic copepods has seldom been investigated in relation to hydrographical features
(Errhif et al., 1997; Fransz and Gonzalez, 1997; Metz, 1995, 1996).

In the present study we examine the structure of small copepod assemblages and the distribution patterns of small copepods in relation to the local hydrographical regime at the APF during the 1995/96 austral summer and discuss their potential effects on ecosystem dynamics.

\section{Material and methods}

\subsection{Investigation area}

Samples were taken during the Polarstern cruise ANT XIII/2 in December/January 1995/96. The study site covers an area of $120 \times 110 \mathrm{~nm}$ across the APF from $49.6^{\circ} \mathrm{S}$ to $50.8^{\circ} \mathrm{S}$ and from $9.5^{\circ} \mathrm{E}$ to $11.5^{\circ} \mathrm{E}$ (Fig. 1a). Hydrographical and biooptical data (Pollard et al., 2002) were obtained from the sea surface down to ca. 350-m depth by means of an undulating vehicle (SeaSoar). CTDMultinet stations (Sts. 21-29) were established immediately after the SeaSoar run along a transect at $10.3^{\circ} \mathrm{E}$, from $49.5^{\circ} \mathrm{S}$ to $50.5^{\circ} \mathrm{S}$ (Fig. 1b). Two additional CTD-Multinet stations-Sts. 15 and 18-were sampled at the southern end of the investigation area, outside the transect. Station 15 was located within a cold feature in the southeast boundary of the study area, and station 18 was established in the southwestern corner of the fine scale SeaSoar grid (Fig. 1b; Pollard et al., 2002).

Pollard et al. (2002) and Read et al. (2002) give detailed information about the hydrographical structure in the study area. Hydrography data at the location of the zooplankton stations as well as a description of the current flow field is provided by Strass et al. (2002). From data obtained by a vessel-mounted acoustic Doppler current profiler (ADCP), Strass et al. (2002) estimated that the maximal drift of any given particle in the surface current of a jet stream associated to the APF corresponds to $0.3 \mathrm{~m} \mathrm{~s}^{-1}$ (Fig. 1c), which translates to $0.5^{\circ}$ in longitude each second day. This in turn was the time span between the SeaSoar runs and the CTDMultinet stations; thus, the water sampled during 

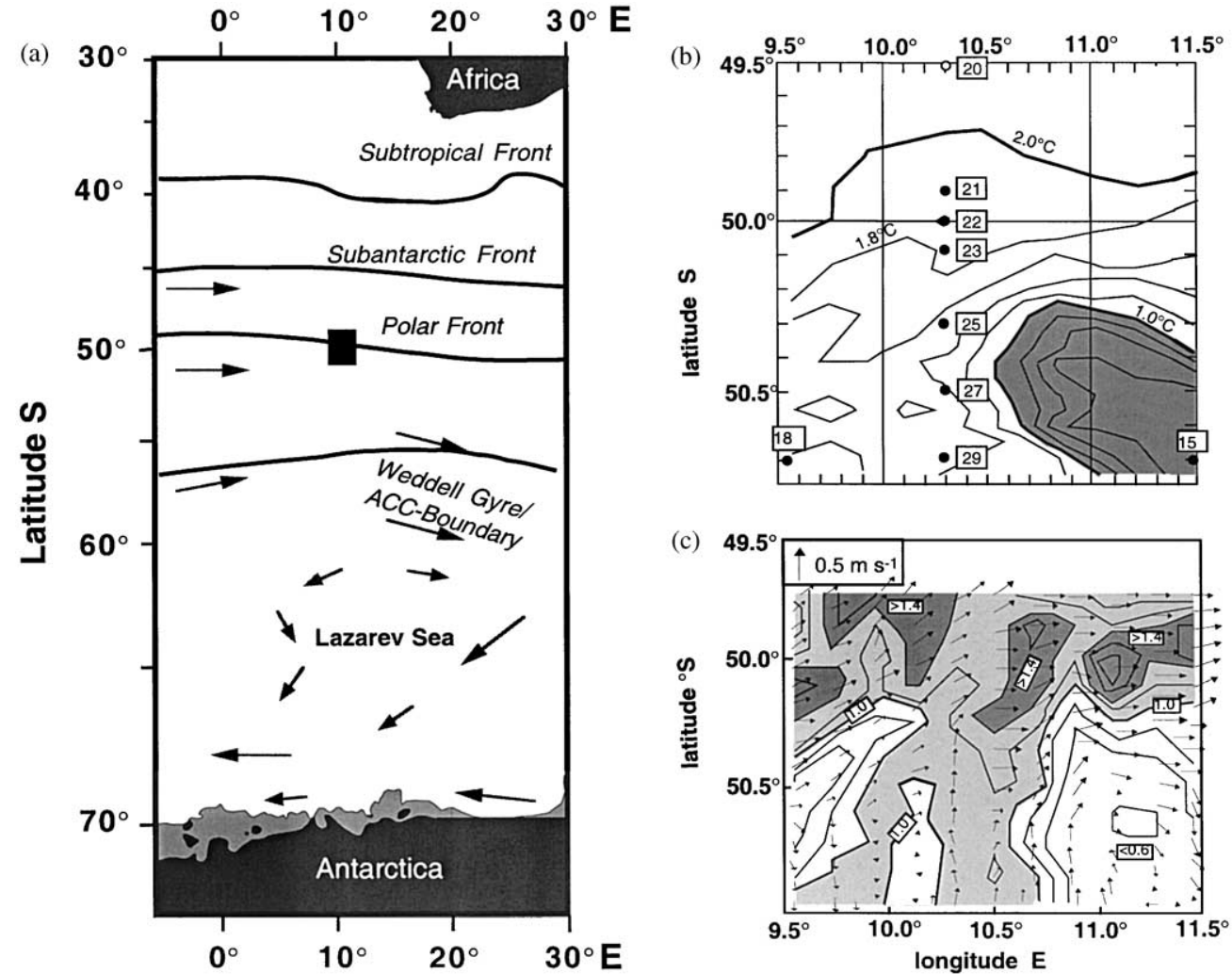

Fig. 1. (a) Position of the investigation area in the South Atlantic (filled square); (b) Position of the CTD-Multinet stations (filled circles) and the CTD-station (open circle). Isotherms at the temperature minimum are added (redrawn after Pollard et al., 2002); and (c) surface chlorophyll $a$ concentrations and current field (data from Strass et al., 2002) in the investigation area.

the CTD-Multinet stations came from within the fine-scale grid covered previously by the SeaSoar. Therefore, we can derive the hydrographical structure within the SeaSoar grid and estimate the coarse origin of the water sampled at each CTD-Multinet station.

\subsection{Zooplankton sampling and sorting procedures}

Zooplankton was collected by vertical hauls of a Multinet (Weikert and John, 1981) equipped with five $100 \mu \mathrm{m}$ mesh nets. We analyzed samples from the following depth strata: 25-0, 50-25, 100-50 and 300-100 m, except for station 21 where the depth strata of 25-0 and 50-25 were combined. Sample volumes were estimated by multiplying the net opening area $\left(0.25 \mathrm{~m}^{2}\right)$ by the length of the corresponding depth layer. Zooplankton samples were split immediately into two aliquots upon retrieval on deck using a Folsom splitter. One of them was fixed in hexamethylentetramin buffered formalin (final concentration of $4 \%$ ), the other was frozen for dry-weight measurements. Preserved samples were further divided into varying aliquots (up to $1 / 128$ of a sample) in the laboratory, employing a Folsom splitter similar to that used aboard ship. A minimum of 300 copepods smaller than $2.0 \mathrm{~mm}$ (as measured with an eyepiece micrometer) was enumerated in the aliquots. Large copepods $(>2.0 \mathrm{~mm})$ are not included in our analysis. Copepodids and adult copepods were identified according to Björnberg (1972, 1981), Heron (1997), and Razouls (1994). Copepodid developmental stages 
were discriminated for the dominant cyclopoid and calanoid species. Nauplii were assigned to genus or family level based on the key provided by Björnberg et al. (1994).

\section{Results}

\subsection{Hydrography}

Our transect crossed two inter-frontal zones south of the subsurface expression of the APF (Belkin and Gordon, 1996), the Northern Polar Frontal Zone (NPFZ), and the Southern Polar Frontal Zone (SPFZ), as defined by the position of the $1.8^{\circ} \mathrm{C}$ isotherm at the temperature minimum (Fig. 1b; see also Pollard et al., 2002). Surfacewater temperature ranged from $4.4^{\circ} \mathrm{C}$, in the northern part of the transect, to $3.8^{\circ} \mathrm{C}$ in the south, while salinity varied between 33.95 and 33.85 (Strass et a1., 1997). The pycnocline was located at about $70-\mathrm{m}$ depth throughout the investigation area, with a variability of $5-10 \mathrm{~m}$ during the 2-week period of investigation.

The edge of a large-scale meander (Strass et al., 2002) protruded northeastward from near station 18 towards the vicinities of transect station 23 . In addition, a cold-core eddy $\left(<1^{\circ} \mathrm{C}\right.$ at the temperature minimum) dominated the southeastern part of the study area around station 15
(Fig. 1b). A cyclonic feature occurred around the center of this cold-water anomaly, associated with a weak northward flow in its western boundary, from station 29 towards station 23 (Fig. 1c). This northward flow was, in turn, also associated with the eastern edge of the abovementioned large meander ridge. Strong eastward and northeastward currents associated with the frontal jet were recorded at about $50^{\circ} \mathrm{S}$ and further north.

The chlorophyll distribution was clearly related to these hydrographic features (Fig. 1c). The transect including stations 20-29 (Fig. 2) was visited about 2 days after the SeaSoar grid (Fig. 1c), so that we have to assume an eastward drift of water masses during this time interval. Transect stations had high chlorophyll $a$ concentrations of up to $1.8 \mu \mathrm{g} \mathrm{chl} a 1^{-1}$ within the upper mixed layer, with maxima at station 21 (Fig. 2, see also Strass et al., 2002). The lowest concentrations (0.6-0.8 $\mu \mathrm{g}$ chl $a 1^{-1}$ ) were measured at stations 22 and 23 which were influenced by the meander feature from the southwest (Fig. 2). A similar range was observed at station 18 , but even lower values occurred at station 15 in the eastern coldcore eddy (Fig. 1c). The bottom of the surface chlorophyll maximum ranged approximately between 50 and $70 \mathrm{~m}$ depth (Fig. 2; see also Strass et al., 2002), thus it coincided with the pycnocline position.

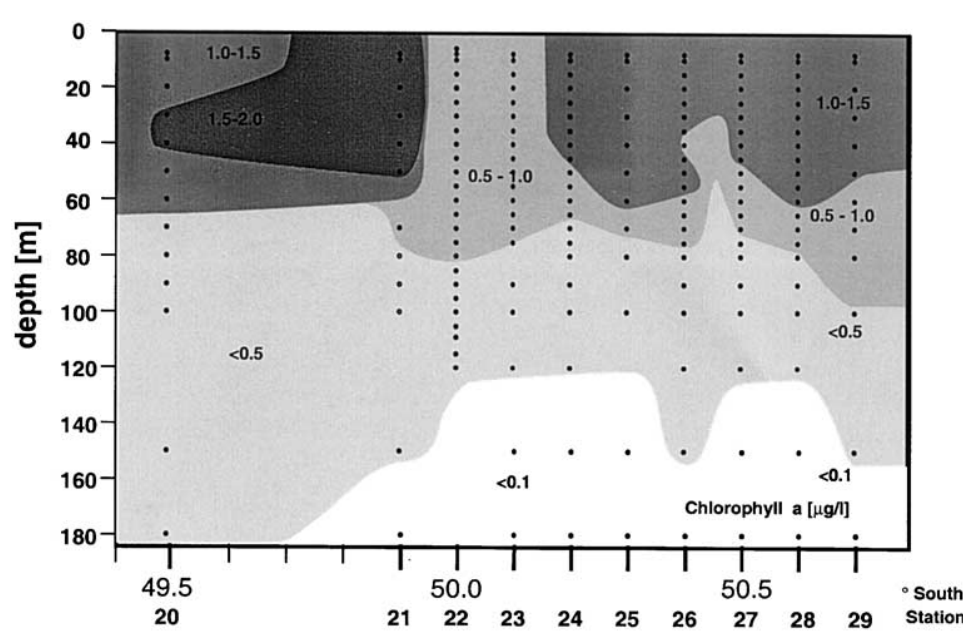

Fig. 2. Chlorophyll $a$ profiles at the CTD-Multinet stations along the $10.3^{\circ} \mathrm{E}$ meridian. 


\subsection{Copepod abundance and distribution}

\subsubsection{Total abundance of copepods in the size} range of $100-2000 \mu \mathrm{m}$

Extremely high copepod abundances (> 25,000 ind. $\mathrm{m}^{-3}$ ) were found in the upper $100 \mathrm{~m}$ of the water column of the stations located in the main frontal jet (Sts. 21-23) and in the northwestern ridge of the cold-core eddy (Sts. 25 and 27) (Fig. 3). A maximum value of approxi- mately 49,000 ind. $\mathrm{m}^{-3}$ was found at station 27. Lower copepod abundances $\left(<20,000\right.$ ind. $\left.\mathrm{m}^{-3}\right)$ were obtained at the southern end of the investigation area (Sts. 29, 18 and 15). Nauplii were usually concentrated above $50 \mathrm{~m}$ depth while copepodids tended to occur at high abundances across the mixed layer down to $100 \mathrm{~m}$ depth. Few copepods were observed in the $300-100 \mathrm{~m}$ depth stratum when compared to the upper layers (Fig. 3).

\section{Total copepod-abundance (size range $100-2000 \mu \mathrm{m}$ )}
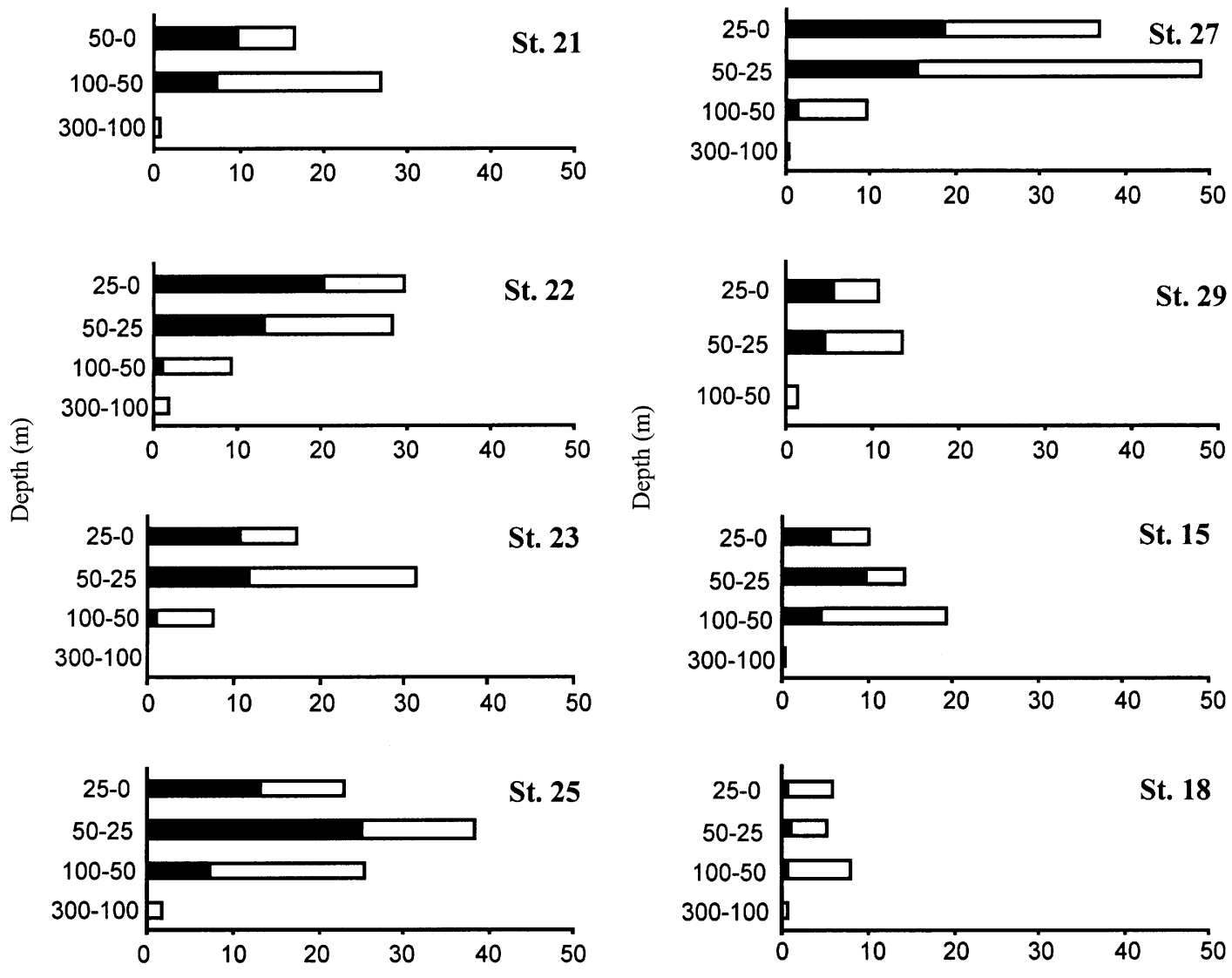

Abundance (103 ind. $\mathrm{m}^{-3}$ )
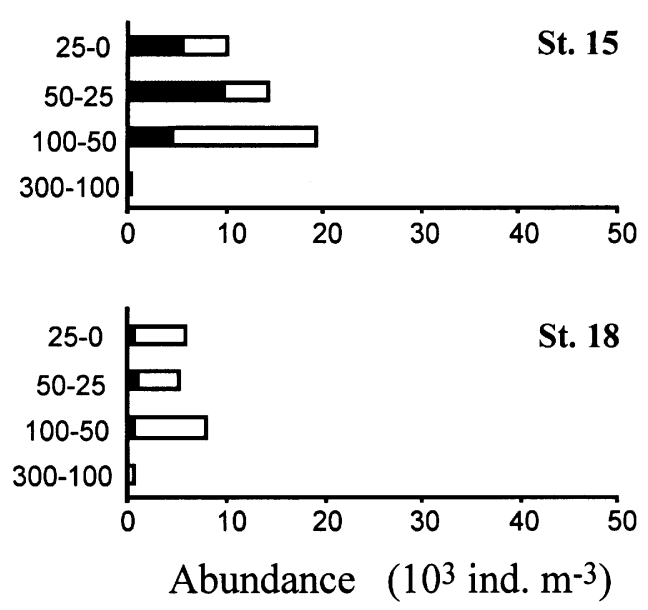

Nauplii $\square$ Copepodids (CI-CV and adults)

Fig. 3. Vertical profiles of the total naupliar and copepodid abundance in the size range 100-2000 $\mu \mathrm{m}$ at the CTD-Multinet stations. 


\subsubsection{Species composition of the copepodids} ( $C I-C V$ and adults)

The cyclopoid Oithona similis was the dominant copepod species in the study area, usually comprising more than $70 \%$ of the total number of young copepodids and adults (Fig. 4). This species occupied the entire mixed layer, and its abundance maxima of more than 10,000 ind $\mathrm{m}^{-3}$ were mostly located in the upper 50 or $100 \mathrm{~m}$. Much lower numbers occurred below $100 \mathrm{~m}$ depth (Fig. 4). At the southernmost stations 29, 15 and
18, O. similis copepodids hardly exceeded 5000 ind. $\mathrm{m}^{-3}$ except for the $100-50 \mathrm{~m}$ depth layer at station 15 (ca. 12,300 ind. $\mathrm{m}^{-3}$ ).

Oithona frigida copepodids were less abundant then Oithona similis, but they also occurred in large numbers: up to 2310 ind. $\mathrm{m}^{-3}$ at stations 22, 23 and 25, with secondary peaks at the southernmost stations 15 and 18 (Fig. 4). The vertical distribution of the pooled $O$. frigida copepodids did not exhibit pronounced differences among depth strata. In the $300-100 \mathrm{~m}$ depth

Copepodids (C I -C V and adults)
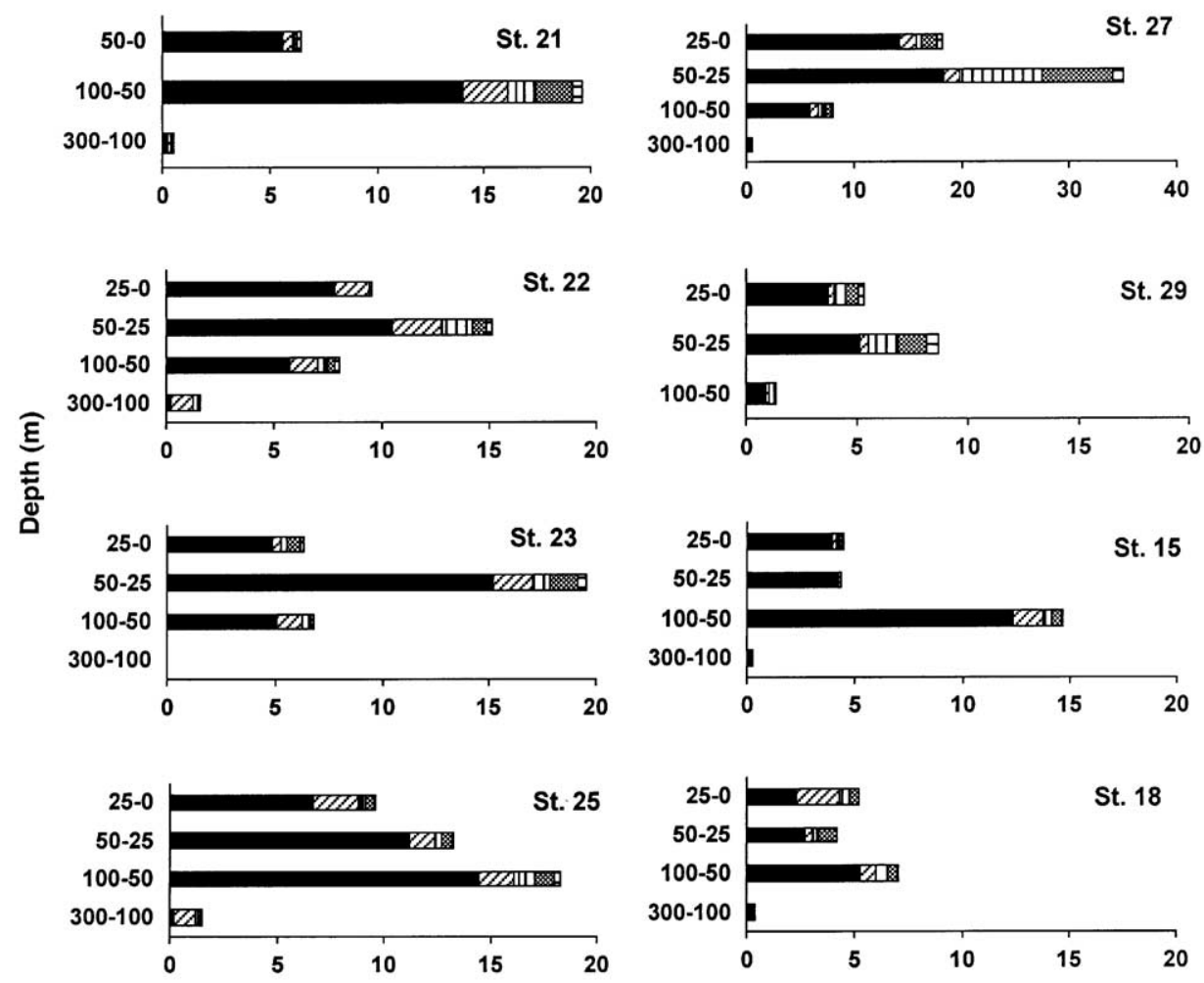

Abundance ( $10^{3}$ Ind. $\mathrm{m}^{-3}$ )

O. similis $\square 0$. frigida $\square$ Oncaea $\square$ Clausocalanidae 日Others

ㅁ Microsetella

Fig. 4. Vertical profiles of copepodid abundance at the CTD-Multinet stations. Note the different scale used for station 27 . The contribution of each taxon to the total copepod abundance is shown. 
layerO. frigida copepodids were more abundant than $O$. similis at most stations with the exception of 15 and 18.

The sub-dominant copepod genera were about one order of magnitude less abundant than Oithona spp. Clausocalanids (mainly Ctenocalanus citer, but also including Microcalanus pygmaeus and Clausocalanus spp.) showed the highest abundances among the calanoid copepods (Fig. 4). Copepodids of this family were recorded mainly down to $100 \mathrm{~m}$ depth, with maximum abundances usually ranging from 500 to 1760 ind. $\mathrm{m}^{-3}$. A remarkable exception was a peak of 6560 ind. $\mathrm{m}^{-3}$ at station 27 (50-25 m depth layer). Relatively few individuals $\left(<300\right.$ ind. $\left.\mathrm{m}^{-3}\right)$ belonging to other calanoid families, such as Metridinidae, Calanidae, and Eucalanidae, were found. They are referred to as "others" in the figures.

The horizontal and vertical distribution of Microsetella sp. matched the pattern observed for

Nauplii
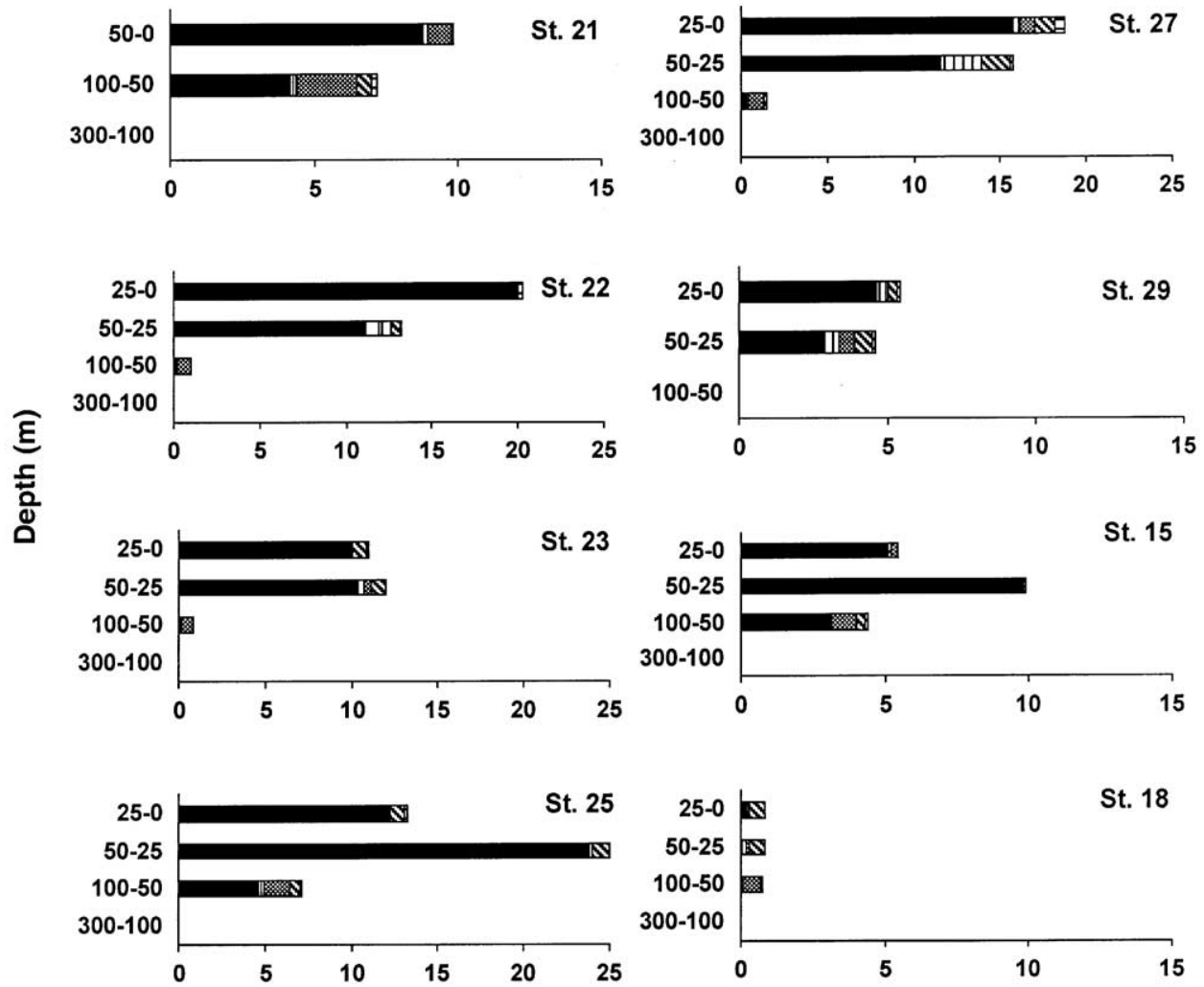

Abundance ( $10^{3}$ Ind. $\left.\mathrm{m}^{-3}\right)$

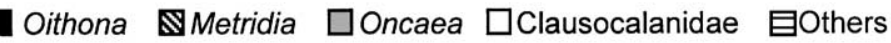

四 Microsetella

Fig. 5. Vertical profiles of the total abundance of copepod nauplii in the size range of 100-2000 $\mu \mathrm{m}$ at each of the investigated stations. The percentage contribution of the dominant taxa is included. Note the different scales. 
clausocalanids, with maximum abundances ranging from 720 to 1040 ind. $\mathrm{m}^{-3}$, besides a peak of 7520 ind. $\mathrm{m}^{-3}$ at station 27 (Fig. 4). Oncaea spp. was more abundant in the $100-50 \mathrm{~m}$ depth stratum, where peak abundances of up to 490 ind. $\mathrm{m}^{-3}$ were recorded.

\subsubsection{Nauplii}

In agreement with our observations on copepodid distribution, Oithona nauplii were about one order of magnitude more abundant than other copepod nauplii (Fig. 5), ranging from only 200 ind. $\mathrm{m}^{-3}$ (St. 18) to 24,000 ind. $\mathrm{m}^{-3}$ (St. 25). Most Oithona nauplii occurred in the northern part of the transect, especially at stations 22 and 25, their numbers decreased towards the South (St. 29). However, relatively high concentrations of Oithona nauplii were found at station 15 , within the cold-water eddy found in the southeastern part of the study area. In all stations sampled, Oithona nauplii were recorded at high numbers within or above the pycnocline (i.e. above $100 \mathrm{~m}$ depth). The subdominant nauplii were those of the Clausocalanidae (Ctenocalanus, Clausocalanus and Microcalanus), Microsetella spp., Metridinidae (Metridia and Pleuromamma), Calanidae (Calanus and $\mathrm{Ca}$ lanoides), and Oncaea spp. Clausocalanid nauplii were more abundant in the $100-50 \mathrm{~m}$ depth layer, with peak densities of up to 2100 ind. $\mathrm{m}^{-3}$ recorded at stations 21 and 25 (Fig. 5). Relatively high abundances of clausocalanid nauplii also were found in surface waters $(25-0 \mathrm{~m}$; sts. 21 and 27), although not exceeding 900 ind. $\mathrm{m}^{-3}$. Metridinid nauplii were recorded at high numbers in the upper layers (above $50 \mathrm{~m}$ depth) of most stations, reaching maximum abundances of up to 2000 ind. $\mathrm{m}^{-3}$ at station 27 (Fig. 5). Although small copepod nauplii were not very abundant in our samples, a peak of 700 ind. $\mathrm{m}^{-3}$ occurred at station 22 , in the $50-25 \mathrm{~m}$ depth layer.

\subsubsection{Stage distribution of Oithona similis, Oithona frigida and Ctenocalanus citer}

The distribution of nauplii and copepodid stages of the dominant species Oithona similis and $O$. frigida was clearly related to depth (Figs. 6-8). The nauplii of Oithona spp. were mainly concentrated in the upper $50 \mathrm{~m}$ of the water column (Fig. 5). At

\section{Oithona similis}
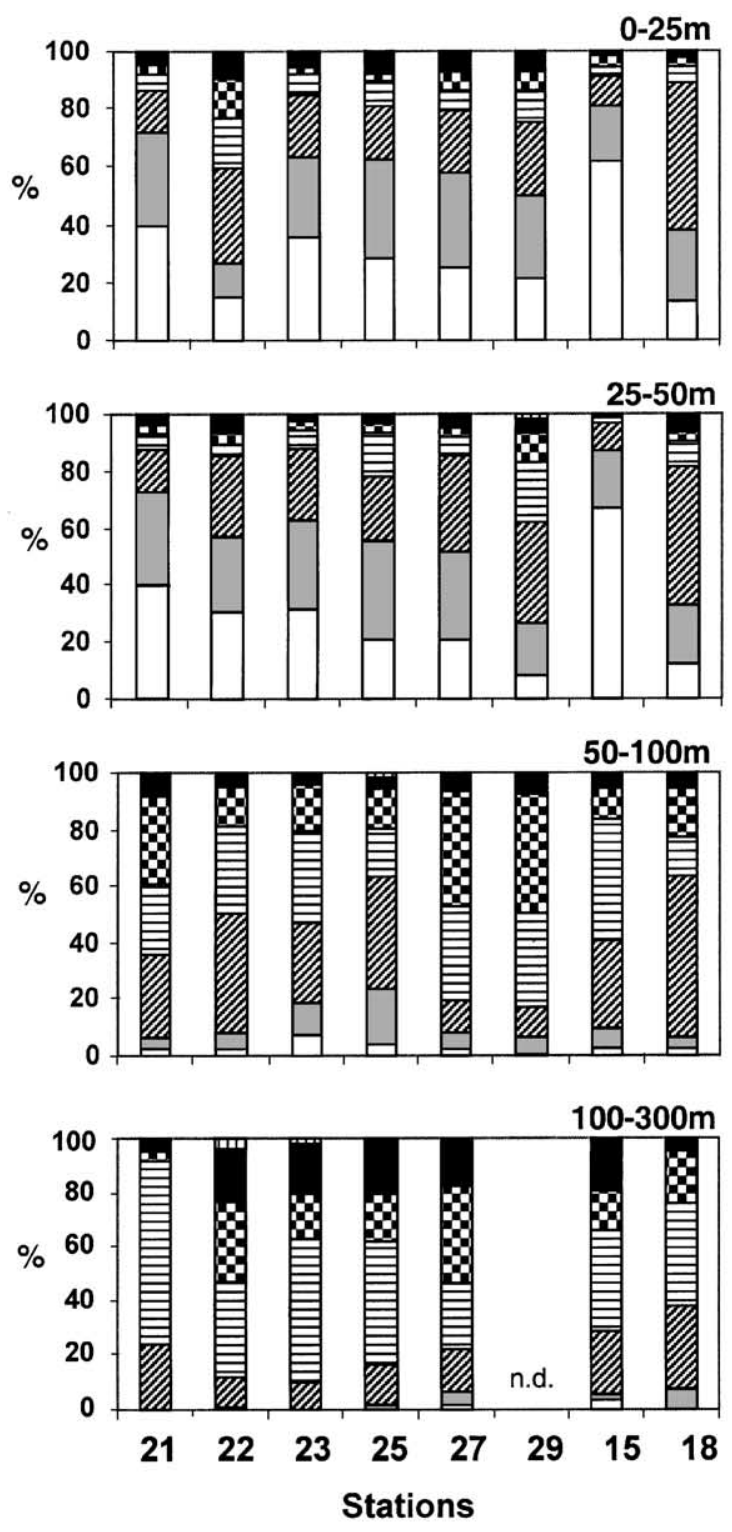

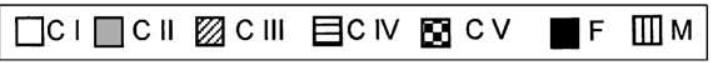

Fig. 6. Stage distribution of Oithona similis at the CTDMultinet stations in different depth layers.

station 18, concentrations and also percentages of oithonid nauplii were remarkably low (Figs. 5 and 8). Young copepodids of $O$. similis (CI-CII) 

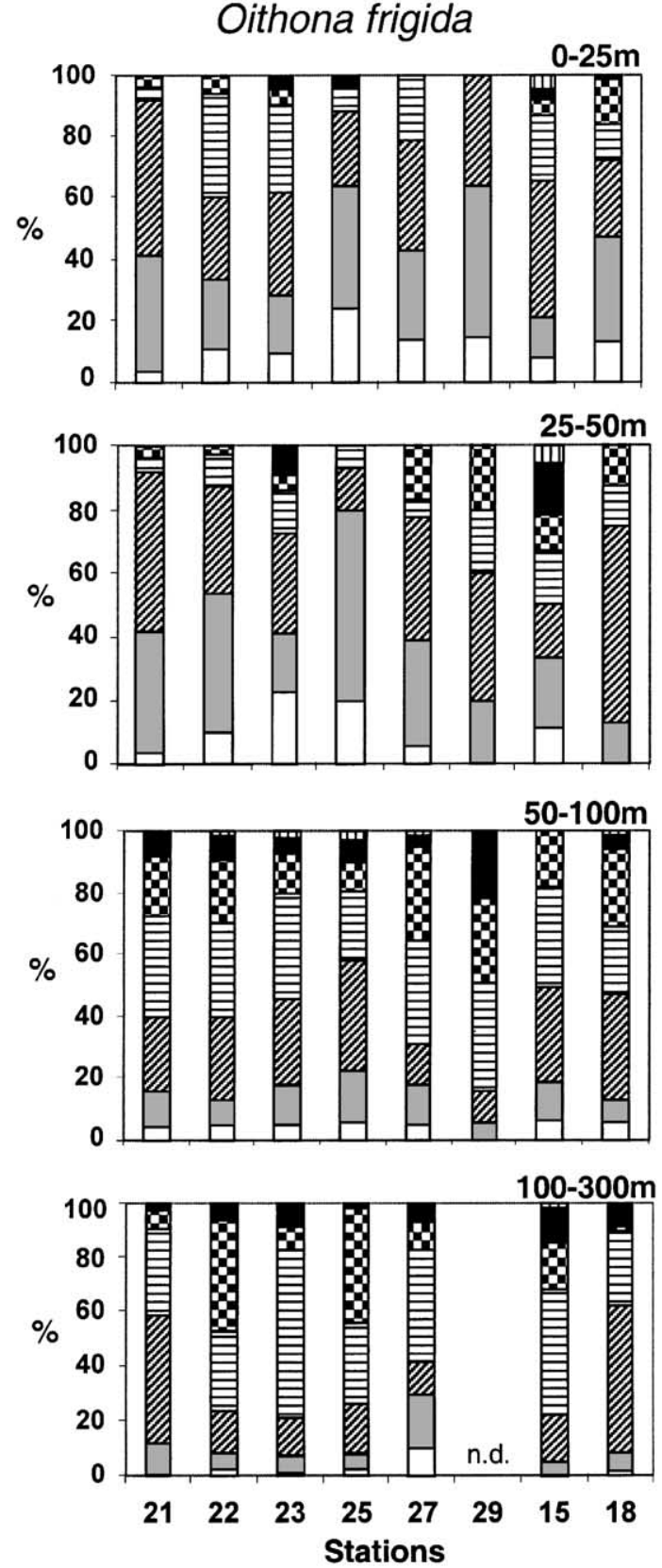

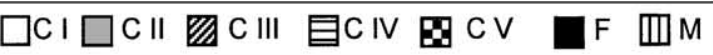

Fig. 7. Stage distribution of Oithona frigida at the CTDMultinet stations in different depth layers.

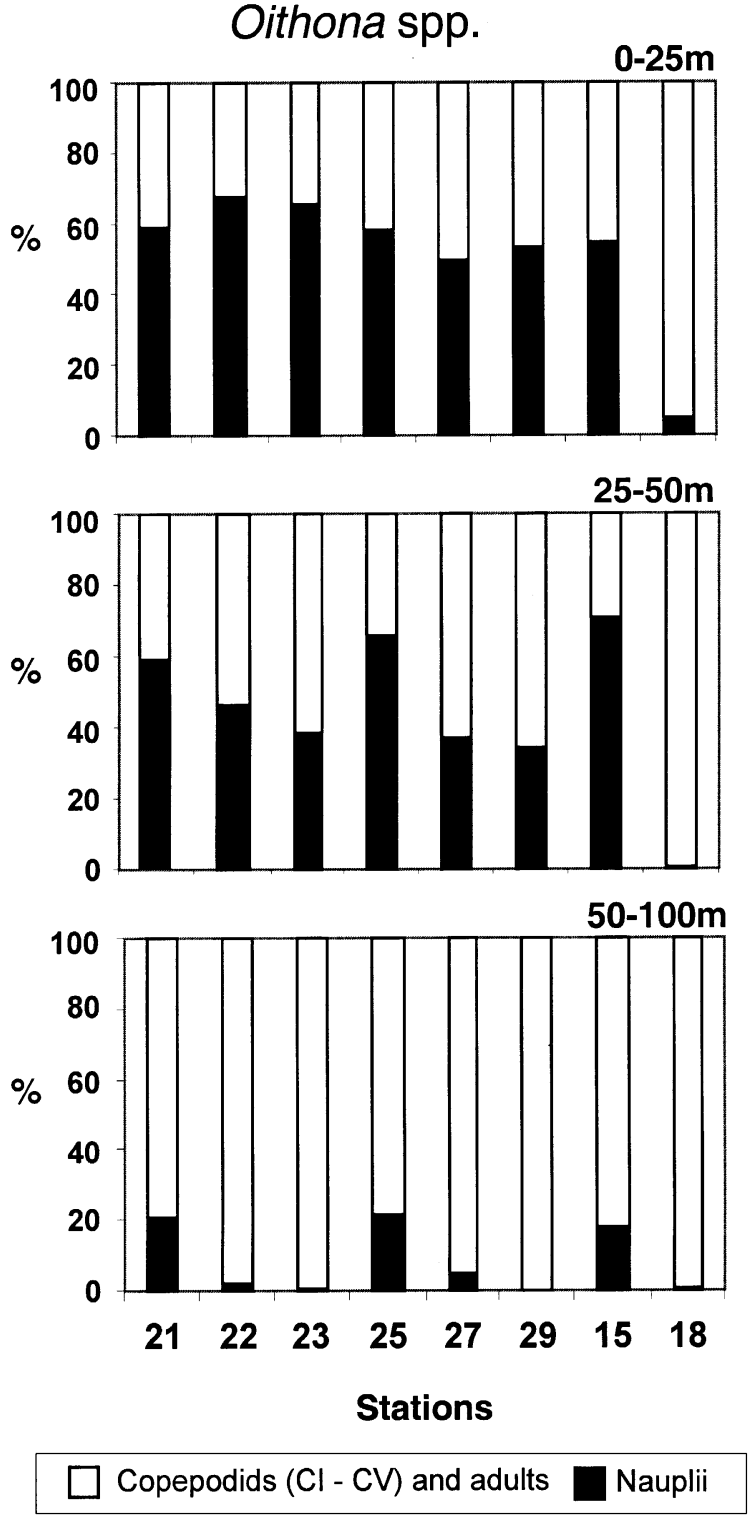

Fig. 8. Percentage of Oithona spp. nauplii at the CTD-Multinet stations in different depth layers. No Oithona nauplii occurred in the depth layer $100-300 \mathrm{~m}$.

usually comprised the majority of the population in the upper layer $(25-0 \mathrm{~m})$, while later stages (CIII-CV) gradually replaced the initial copepodids from surface down to $100 \mathrm{~m}$ depth (Fig. 6). Copepodids IV, V and adults were the dominant stages of $O$. similis below $100 \mathrm{~m}$ depth, although 

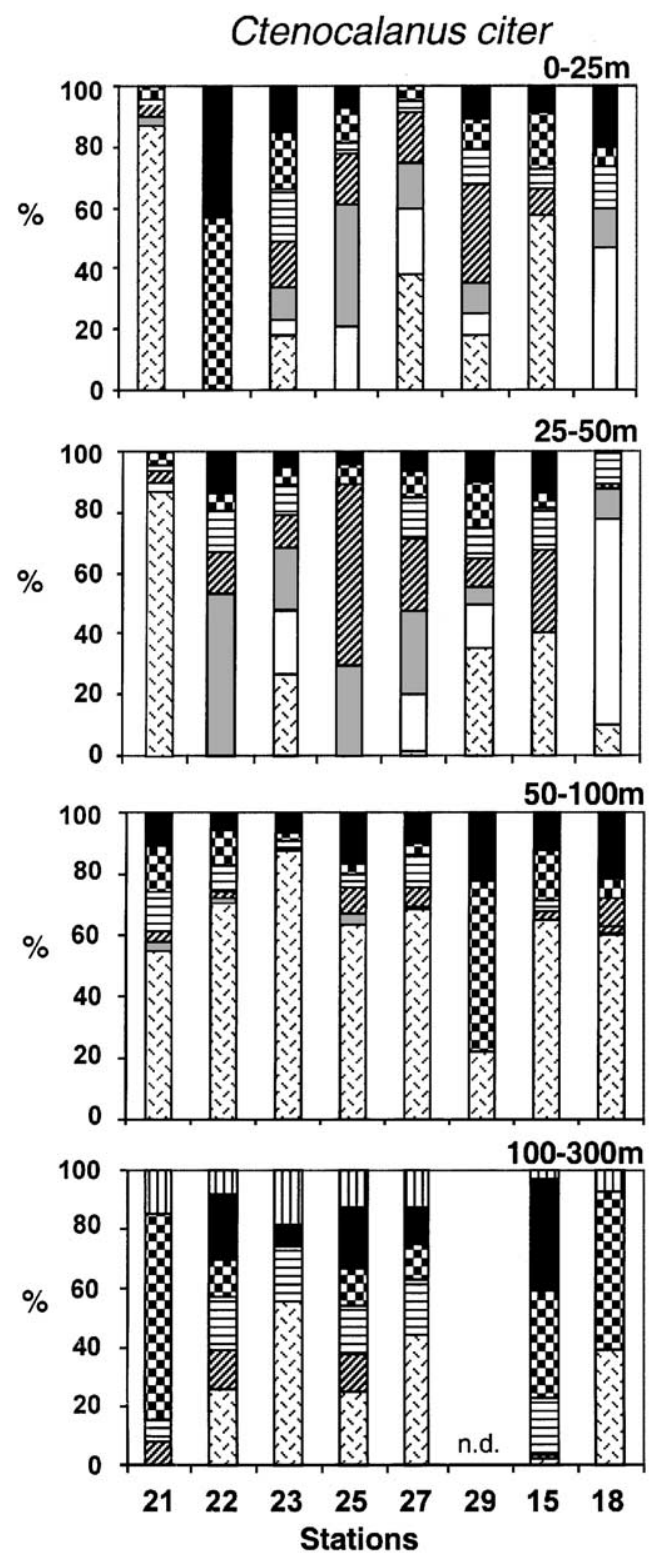

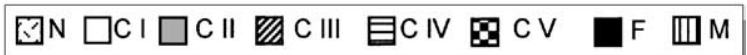

Fig. 9. Stage distribution of Ctenocalanus citer at the CTDMultinet stations in different depth layers.

one must note that the total abundance of this species in this layer was low (Fig. 4). The initial stages of $O$. frigida copepodids were also more abundant in the upper depth strata (Fig. 7).
CI-CIII formed the bulk of the population above $50 \mathrm{~m}$ depth, while copepodids CIV and CV usually dominated at greater depths (Fig. 7).

Whereas the nauplii of Oithona spp. occurred only down to $100 \mathrm{~m}$, the nauplii of Ctenocalanus citer were also found in the depth layer of $300-$ $100 \mathrm{~m}$ (Figs. 8 and 9), but in very low numbers. Ctenocalanus citer displayed a more complicated vertical pattern, with high variability among stations in the uppermost layer $(25-0 \mathrm{~m})$ : while at stations 25, 27 and 29 young copepodids (CICIII) represented the dominant stages, only later copepodids (CV) and adult females were found at station 22 (Fig. 9). The stages CIV, CV and females usually comprised the bulk of the copepodid population below $25 \mathrm{~m}$ depth (Fig. 9). Males were found at all stations but mainly in the depth layer of $300-100 \mathrm{~m}$.

\section{Discussion}

\subsection{High abundances of zooplankton (size range $100-2000 \mu \mathrm{m}$ )}

Small copepods in the size range of 100 $2000 \mu \mathrm{m}$ were extremely abundant in the upper mixed layer of most of the transect stations, reaching up to 49,000 ind. $\mathrm{m}^{-3}$. These concentrations were much higher than values obtained by Fransz and Gonzalez (1997), Errhif et al. (1997) and Atkinson and Sinclair (2000) in the APF and nearby systems. Investigations in more southern regions of the Antarctic Ocean, such as coastal regions near the South Shetland Islands (Chojnacki and Weglenska, 1984; Park and Wormuth, 1993; Ward et al., 1995), the Scotia Sea (Marin, 1987), the Weddell Sea (Hopkins and Torres, 1988; González et al., 1994), the Bellingshausen Sea (Metz, 1996), and an coastal area of Eastern Antarctica (Tucker and Burton, 1990), also revealed much lower numbers. Our results confirm previous findings, which indicate a very large zonal increase of Oithona abundance from the coldest water in the south across the entire Southern Ocean towards the vicinity of the Polar Front where maximum numbers seem to be recurrent (e.g., Metz, 1996; Fransz and Gonzalez, 
1997; Atkinson, 1998; Atkinson and Sinclair, 2000); still our values at the APF exceed previously reported concentrations of Oithona spp. and other small copepods. Our results are consistent with the zooplankton abundance data derived from the OPC runs conducted during the same cruise (Pollard et al., 2002), taking into account the OPC size classes relevant to the Multinet samples (0.25-0.5 and 0.5-1.0 mm ESD), and after applying the necessary calibrations. Despite the high numbers of nauplii caught by the $100-\mu \mathrm{m}$ Multinet, we have missed an unknown but probably high percentage of younger naupliar stages due to their small size. This is valid especially for the noncalanoid orthonauplii, which can be as small as $50 \mu \mathrm{m}$ (Björnberg, 1972; Fransz, 1988). The current results are thus realistic compared to the OPC data and other previous investigations (Fransz and Gonzalez, 1997).

The fact that we found an exceptionally high abundance of small copepods during the Polarstern cruise ANT XIII/2 arises from a combination of factors. First, the sampling gear employed was appropriate to catch the target organisms in the size range of $200-2000 \mu \mathrm{m}$, although our results probably still represent an underestimate of the actual abundance of small copepods, mainly juveniles and nauplii, in the APF. Obviously the $100-\mu \mathrm{m}$ mesh sized net retained the larger nauplii and young copepodid stages with greater efficiency than the most commonly used $200-$ or $300-\mu \mathrm{m}$ mesh sized nets (Barnes and Tranter, 1965). Second, narrow bands of high chlorophyll and zooplankton standing-stocks, characteristic for frontal activities (e.g. Franks, 1992), can now be remotely detected by continuous sampling using fluorescence probes and optical counters mounted on towed instruments such as the SeaSoar. This has considerably improved our ability to recognize and investigate in more detail areas of high plankton abundance in the open ocean.

Nauplii and copepodids of the genus Oithona and, to a lesser extent, Ctenocalanus were the numerically dominant copepods in the APF during the summer of $1995 / 96$. Oithona spp. occurs in high numbers in most regions of the Southern Ocean, and its importance for the Antarctic ecosystem is of no doubt (e.g., Fransz, 1988;
Fransz and Gonzalez, 1995; Metz, 1995, 1996; Fransz and Gonzalez, 1997; Atkinson and Sinclair, 2000). In contrast to larger calanoid copepods, Oithona spp. undergoes no seasonal migration (Fransz and Gonzalez, 1995; Atkinson and Sinclair, 2000) but remains year-round in the top $200 \mathrm{~m}$ of the water column. Fransz and Gonzalez (1995) report that egg production of Oithona is more spread over the seasons than reported for calanoid copepods. This leads to a mixing of age classes, which also was found during our studies. Since egg production of Oithona spp. possibly starts before the onset of spring phytoplankton bloom, this species is able to build up large numbers earlier than the larger calanoid copepods and they are often able to make a second generation per year. Metz (1996) generally found adults of Oithona in deeper water layers than the juveniles and supposed avoidance of predators. According to Kellermann (1987), Oithona adults are important food items for fish larvae ("visual hunters"), so that the adults prefer to stay in deeper water layers. In our studies, older stages also occurred in higher percentages in deeper water layers.

Ctenocalanus citer also occurred in surprisingly high numbers in our investigation area. This species is found in most Antarctic waters, e.g., the Weddell Sea (Kaczmaruk, 1983; SchnackSchiel and Mizdalski, 1994) and near the Antarctic Peninsula (Zmijewska, 1988), but in much lower abundances. Atkinson and Sinclair (unpublished data) did further analyses of the Discovery samples covering a large area of the Atlantic sector of the Antarctic Ocean. They also found an increase of $C$. citer concentrations in the Polar Front compared to more southern and northern areas. Thus, the high abundance of $C$. citer seems to be a typical feature of the frontal area. Ctenocalanus citer also is a rather weak seasonal migrant (Atkinson and Sinclair, 2000), and is able to grow and reproduce before the onset of phytoplankton blooms in the water column (Schnack-Schiel and Mizdalski, 1994). Thus both species, Oithona spp. and Ctenocalanus citer start to grow and proliferate early during spring.

The maximum abundance found during our investigations was roughly 5-10 times higher than 
the values obtained by Fransz and Gonzalez (1997) during spring in the APF. We assume that during spring, a certain amount of smaller copepods are concentrated in the APF, already leading to a higher abundance compared with the surrounding waters. Since the growth conditions in the APF are very favorable, in terms of high phytoplankton concentrations (Bathmann et al., 1997), as they present good food supply and higher temperatures compared to the more southern water, the population can proliferate rapidly. The stage distribution of the dominant species supports the suggestion that the abundance of small pelagic copepods increases at the APF during early summer: adult females and copepodids belonging to stage $\mathrm{CV}$ comprised more than $60 \%$ of the Oithona similis abundance during spring (Fransz and Gonzalez, 1997). However, there is a shift in the mean stage towards summer since we found that most of the $O$. similis population in the upper $50 \mathrm{~m}$ of the water column was made up of nauplii and copepodid stages younger than CIV (Fig. 6). The same situation was found in the population structure of Ctenocalanus citer, which was also dominated by nauplii and younger stages during summer. This decrease in mean stage from spring to summer presumably arises from enhanced recruitment rates of oithonids and small calanoids, implying that both adult females and nauplii were experiencing favourable food conditions during early summer.

Highest concentrations of copepods were found closely associated with the frontal jet, whereas the more southern stations (Sts. 15, 18 and 29) were characterized by much lower concentrations of zooplankton (Fig. 3). These results probably reflect the effects of physical processes on copepod populations. Voronina (1968) demonstrated that the downwelling in the Antarctic Convergence Zone leads to an increase of zooplankton abundance in this area. Also Strass et al. (2002) and Read et al. (2002) have shown that zooplankton distributions are constrained by the meandering structure of the frontal system south of $49^{\circ} \mathrm{S}$, and that higher biovolumes occur in warm, downwelling waters rather than in the upwelling edge of the meandering features. The presence of eddy-like structures, in combination with the pronounced current field (up to $0.3 \mathrm{~m} \mathrm{~s}^{-1}$ ) at the frontal jet (Strass et al., 2002) provide efficient retention systems as they inhibit the advective transport of small metazooplankton out of the frontal area. The structure and the dynamics of the meandering features may thus contribute to the increase of the residence time of the copepods in an adequate food regime (Fransz and Gonzalez, 1997), favoring both the biomass buildup and the persistence of resident populations.

\subsection{Potential role of small pelagic copepods in the frontal ecosystem}

The Antaretic Poar Front (APF) is characterized by the frequent occurrence of phytoplankton blooms of up to $4 \mathrm{mg} \mathrm{Chl} a \mathrm{~m}^{-3}$ during spring (Bathmann et al., 1997). These spring blooms are dominated by large and often chain-forming phytoplankton such as Fragillariopsis kerguelensis, Corethron inerme, and Corethron criophilum (Bathmann et al., 1997; Crawford, 1995; Crawford et al., 1997). Grazing of the larger copepod species (Rhincalanus gigas and Calanoides acutus) accounted for $<1 \%$ of the daily primary production during spring (Dubischar and Bathmann, 1997). Thus, their influence on phytoplankton dynamics in this region is rather low. The same holds true for the summer situation, when the phytoplankton community also was dominated by heavily silicified spiny, or chain-forming diatoms such as Chaetoceros spp., Thalassiothrix spp., and Pseudonitzschia spp. (Klass et al., 1997). The abundance of larger copepods such as Rhincalanus gigas, Calanoides acutus, and Calanus simillimus (about 25 ind. $\mathrm{m}^{-3}$ (Dubischar, 2000)), and their resulting grazing pressure was not high enough to control phytoplankton growth.

In contrast, an estimation of the potential impact of the smaller zooplankton species on the structure of the frontal ecosystem suggests that they play an important role in this area. Assuming a carbon demand of ca. $100 \%$ of the body carbon (Atkinson, 1994; Swadling et al., 1997) and a body weight of about $1 \mu \mathrm{g}$ C for Oithona similis (Fransz and Gonzalez, 1997; Swadling et al., 1997), we calculated a potential carbon demand of $1 \mathrm{~g} \mathrm{C} \mathrm{m}^{-2} \mathrm{~d}^{-1}$ integrated over the top $100 \mathrm{~m}$ in 
the center of the APF and ca. $600 \mathrm{mg}$ at the more southern stations (Sts. 15, 18 and 29). This would account for $>100 \%$ of the daily primary production of $750-950 \mathrm{mg} \mathrm{C} \mathrm{m}^{-2} \mathrm{~d}^{-1}$ (Bracher et al., 1999). This number presumably is the maximum potential feeding rate, because the assumed $1 \mu \mathrm{g} \mathrm{C}$ copepod $^{-1}$ day $^{-1}$ might be an overestimate for the smaller copepodites of Oithona. Unfortunately, we do not have microscopic evidence of feeding impact of Oithona on the microheterotrophic community at the APF, but investigations dealing with the feeding behaviour of Oithona spp. indicated that this species is not able to feed on larger diatoms but prefers smaller food organisms, preferentially small nano- or dinoflagellates and ciliates (Atkinson, 1995, 1996) and faecal material (González and Smetacek, 1994). This could explain the low concentrations of smaller plankton organisms found in the frontal area during our investigations, where less than $30 \%$ of the chlorophyll standing stock belong to the size classes below $20 \mu \mathrm{m}$ (Bracher et al., 1999). Also the very low concentrations of faecal material in this region (Dubischar and Bathmann, 2002) might be due to this special feeding mode. In addition, bacterivory by copepod nauplii (Roff et al., 1995; Turner and Tester, 1992) and nanoheterotrophs (Becquevort, 1997) might account for the rather low but constant bacterial concentrations of $0.4-2.0 \times 10^{6} \mathrm{ml}^{-1}$ found in the upper mixed layer of the APF (Lochte et al., 1997).

Such an intense feeding on phytoplankton, detrital material, and zooplankton faeces by small copepod species within the euphotic zone should result in high turnover of material within the surface layer and, in turn, in low vertical mass flux. This is consistent with the rather low sedimentation rates $(12-24 \%$ of primary production) out of the surface layers of the APF during the present investigation (Rutgers van der Loeff et al., 2002), where ${ }^{234}$ Th-isotope information was used to calculate the vertical particle flux.

All these observations strongly suggest that the smaller mesozooplankton in the region of the APF may effectively recycle organic matter (living cells or detritus) within the upper layers of the water column. In this respect our observations support the hypothesis of Smetacek et al. (1990), that a regenerative plankton community composed of micro-autotrophs and micro-heterotrophs builds the basis of the Antarctic pelagic food web, whereas the bulk of the biomass during the large phytoplankton blooms is mainly contributed by large diatoms. There are several mechanisms whereby small calanoid and cyclopoid copepods and the early developmental stages of all copepods may play an important role in regulating the plankton community structure in the Southern Ocean. Since the small copepods feed very actively on smaller plankton particles, faecal material, and detritus, they efficiently recycle the nutrients within the upper water column. Larger diatoms, such as Thalassiothrix and Corethron are not affected by the grazing of the smaller copepods but can use the recycled nutrients. Thus, the activities of the small copepods may indirectly support the buildup of the large phytoplankton blooms dominated by large diatoms. Future work should give more focus to this aspect of the pelagic ecology of the Antarctic.

Another aspect of these high abundances of zooplankton in this region is the potential attraction of larger migratory predators (Hamner, 1988). The APF has been characterized by high biomass of large zooplankton, ichthyoplankton, and myctophid fishes, as compared with the surrounding water masses (Foxton, 1956; Hopkins, 1971; Maslennikov and Solyankin, 1993). Also van Franeker et al. (2002) found a clear match between the small-scale horizontal occurrence of prions (Pachyptila sp.) and the area of high zooplankton abundance in the upper ocean layers of the APF during spring. Prions feed by sieving water through the gills of their beak (van Franeker et al., 2002) and are therefore capable of concentrating the small zooplankton during flight just above the water. The occurrence of prions also coincided with the zooplankton distribution derived from the SeaSoar-mounted OPC (van Franeker et al., 2002). Thus, besides being eaten by top pelagic predators, small copepods also may represent a major food source for some seabirds of the open Antarctic Ocean. If our assumptions hold true, these copepods are key elements in the transfer of organic matter (and thus energy) from 
the recycling pelagic community to the higher trophic food levels.

\section{Conclusions}

The abundance of small $(<2.0 \mathrm{~mm})$ pelagic copepods at the APF during early summer is comparable to the highest figures reported for productive coastal ecosystems of the northern hemisphere (e.g., Nielsen and Richardson, 1989; Turner, 1994; Turner and Dagg, 1983). Although the use of a $100-\mu \mathrm{m}$ mesh sized Multinet contributed to a better estimation of the abundance of the small calanoids and cyclopoids, several physical and ecological factors may have accounted for the reported results. Mainly two physical factors may increase plankton abundance in the APF: first, the downwelling taking place in this region concentrates plankton in the surface layers (Voronina, 1968), and second, the structure and the meandering features may contribute to an increase of the residence time in this region. These two factors promote the retention of copepod populations within a food-enriched environment, and allows strong biomass accumulation during the productive season. This is reflected by a 5-fold increase in the numerical abundance of small copepods from spring (Fransz and Gonzalez, 1997) through summer. The dominant epipelagic species (Oithona similis and Ctenocalanus citer) breed during early summer at the APF, as indicated by the high abundance of their nauplii. Our limited observations also suggest that Oithona frigida display a similar reproductive behavior.

The data presented here support the hypothesis that small copepod species and early developmental stages of all pelagic copepods are key components of the planktonic food web of the Southern Ocean, especially in the APF. The metabolic activity of these small metazoans seems to play a major role in controlling food web dynamics in this region. There is an urgent need of additional information on the fine-scale distribution, reproductive behavior, and food web interactions of small pelagic copepods at the APF. In addition, we reinforce the recommendations of Conover and
Huntley (1991) that further sampling with suitable gear is required to clarify our understanding of the ecological relevance of small copepods in the Southern Ocean.

\section{Acknowledgements}

We thank the captain, the officers and the crew of R.V. Polarstern for their skilful help and the thoughtful guidance throughout the entire cruise ANT XIII/2 by chief scientist Victor Smetacek. We also are grateful to Dr. Sigrid Schnack-Schiel for providing the laboratory facilities needed to analyze the zooplankton samples. Partial financial support for this work was provided by the Brazil/ Germany bilateral cooperation program $(\mathrm{CNPq} /$ WTZ agreement, project MAR 35/98-BRA35) and by a CNPq grant to RML (Proc. 301385/971). We also wish to thank Ruth Alheit, Angus Atkinson, George Fransz, Christian Hamm and one anonymous reviewer for their very valuable comments on the manuscript.

\section{References}

Atkinson, A., 1994. Diets and feeding selectivity among the epipelagic copepod community near South Georgia in summer. Polar Biology 14, 551-560.

Atkinson, A., 1995. Omnivory and feeding selectivity in five copepod species during spring in the Bellingshausen Sea, Antarctica. ICES Journal of Marine Science 52, 385-396.

Atkinson, A., 1996. Subantarctic copepods in an oceanic, low chlorophyll environment: ciliate predation, food selectivity and impact on prey populations. Marine Ecology Progress Series 130, 85-96.

Atkinson, A., 1998. Life cycle strategies of epipelagic copepods in the Southern Ocean. Journal of Marine Systems 15, 289-311.

Atkinson, A., Sinclair, J.D., 2000. Zonal distribution and seasonal vertical migration of copepod assemblages in the Scotia Sea. Polar Biology 23, 46-58.

Barnes, H., Tranter, D.J., 1965. A statistical examination of the catches, numbers and biomass taken by three commonly used plankton nets. Australian Journal of Marine and Freshwater Research 16, 293-306.

Bathmann, U.V., Makarov, R.R., Spiridonov, V.A., Rohardt, G., 1993. Winter distribution and overwintering strategies of the Antarctic copepod species Calanoides acutus, Rhincalanus gigas and Calanus propinquus (Crustacea, Calanoida) in the Weddell Sea. Polar Biology 13, 333-346. 
Bathmann, U.V., Scharek, R., Klaas, C., Dubischar, C.D., Smetacek, V., 1997. Spring development of phytoplankton biomass and composition in major water masses of the Atlantic sector of the Southern Ocean. Deep-Sea Research II 44, 51-68.

Becquevort, S., 1997. Nanoprotozooplankton in the Atlantic sector of the Southern Ocean during early spring: biomass and feeding activities. Deep-Sea Research II 44, 355-373.

Belkin, I.M., Gordon, A.L., 1996. Southern Ocean fronts from the Greenwich meridian to Tasmania. Journal of Geophysical Research 101 (C2), 3675-3696.

Björnberg, T.K.S., 1972. Developmental stages of some tropical and subtropical planktonic marine copepods. Studies on the Fauna of Curaçao and other Caribbean Islands 136, 5-113.

Björnberg, T.K.S., 1981. Copepoda. In: Boltovskoy, D. (Ed.), Atlas del zooplancton del Atlantico Sudoccidental y métodos de trabajo com el zooplancton marino. INIDEP, Mar del Plata, pp. 587-679.

Björnberg, T.K.S., Lopes, R.M., Björnberg, M.H.G.C., 1994. Chave para a identificação de náuplios de copépodos planctônicos marinhos do Atlântico Sul-Ocidental. Nauplius 2, 1-16.

Bracher, A.U., Kroon, B.M.A., Lucas, M.I., 1999. Primary production, physiological state and composition of phytoplankton in the Atlantic sector of the Southern Ocean. Marine Ecology Progress Series 190, 1-16.

Chojnacki, J., Weglenska, T., 1984. Periodicity of composition, abundance, and vertical distribution of summer zooplankton (1977/1978) in Ezcurra Inlet, Admiral Bay (King George Island, South Shetland). Journal of Plankton Research 6, 997-1017.

Conover, R.J., Huntley, M., 1991. Copepods in ice-covered seas-Distribution, adaptations to seasonally limited food, metabolism, growth patterns and life cycle strategies in polar seas. Journal of Marine Systems 2, 1-41.

Crawford, R.M., 1995. The role of sex in the sedimentation of a marine diatom bloom. Limnology and Oceanography 40, 200-204.

Crawford, R.M., Hinz, F., Rynearson, T., 1997. Spatial and temporal distribution of assemblages of the diatom Corethron criophilum in the Polar Frontal region of the South Atlantic. Deep-Sea Research II 44, 479-496.

Dubischar, C.D., 2000. Mesozooplankton an der Polarfront des Südlichen Ozeans: Artenzusammensetzung, Verteilung und Rolle im Pelagial. Ph.D. Thesis, University of Bremen, 199pp.

Dubischar, C.D., Bathmann, U.V., 1997. Grazing impact of copepods and salps on phytoplankton in the Atlantic sector of the Southern Ocean. Deep-Sea Research II 44, 415-433.

Dubischar, C.D., Bathmann, U.V., 2002. The occurrence of faecal material in relation to different pelagic systems in the Southern Ocean and its importance for vertical flux. DeepSea Research II 49, 3229-3242.

Errhif, A., Razouls, C., Mayzaud, P., 1997. Composition and community structure of pelagic copepods in the Indian sector of the Antarctic Ocean during the end of the austral summer. Polar Biology 17, 418-430.

Foster, B.A., 1987. Composition and abundance of zooplankton under the spring sea-ice of McMurdo Sound, Antarctica. Polar Biology 8, 41-48.

Foxton, P., 1956. The distribution of the standing crop of zooplankton in the Southern Ocean. Discovery Reports 28, 191-236.

Franks, P.J.S., 1992. Sink or swim: accumulation of biomass at fronts. Marine Ecology Progress Series 82, 1-12.

Fransz, H.G., 1988. Vernal abundance, structure and development of epipelagic copepod populations of the Eastern Weddell Sea (Antarctica). Polar Biology 9, 107-114.

Fransz, H.G., Gonzalez, S.R., 1995. The production of Oithona similis (Copepoda: Cyclopoida) in the Southern Ocean. ICES Journal of Marine Science 52, 549-555.

Fransz, H.G., Gonzalez, S.R., 1997. Latitudinal metazoan plankton zones in the Antarctic Circumpolar Current along $6^{\circ}$ during austral spring 1992. Deep-Sea Research II 44, 395-414.

González, H.E., Smetacek, V., 1994. The possible role of the cyclopoid copepod Oithona in retarding vertical flux of zooplankton faecal material. Marine Ecology Progress Series 113, 233-246.

González, H.E., Kurbjeweit, F., Bathmann, U.V., 1994. Occurrence of cyclopoid copepods and faecal material in the Halley Bay region, Antarctica, during January-February 1991. Polar Biology 14, 331-342.

Hamner, W.M., 1988. The "lost year" of the sea turtle. Trends in Ecology and Evolution 3, 116-118.

Hardy, A.C., Gunther, E.R., 1935. The plankton of the South Georgia whaling grounds and adjacent waters, 1926-1927. Discovery Reports 11, 1-456.

Heron, G.A., 1997. Twenty-six species of Oncaeidae (Copepoda: Cyclopoida) from the southwest Pacific-Antarctic area. Antarctic Research Series 26, 37-96.

Hopkins, T.L., 1971. Zooplankton standing crop in the Pacific sector of the Antarctic. Marine Biology 89, 197-212.

Hopkins, T.L., Torres, J.J., 1988. The zooplankton community in the vicinity of the ice edge, Western Weddell Sea, March 1986. Polar Biology 9, 79-87.

Huntley, M.E., Niller, P.P., 1995. Physical control of population dynamics in the Southern Ocean. ICES Journal of Marine Science 52, 457-468.

Kaczmaruk, B.Z., 1983. Occurrence and distribution of the Antarctic copepods along the ice shelves in the Weddell Sea in summer 1979/1980. Meeresforsch 30, 25-41.

Kellermann, A., 1987. Food and feeding ecology of postlarval and juvenile Pleurogramma antarcticum (Pisces; Notothenioidei) in the seasonal pack ice zone off the Antarctic Peninsula. Polar Biology 7, 307-315.

Klass, C., Kühn, S., Menden-Deuer, S., Reynarson, T., Smetacek, V., 1997. Phytoplankton and heterotrophic protist counts. Berichte zur Polarforschung 221, 68-71.

Lochte, K., Bjørnsen, P.K., Giesenhagen, H., Weber, A., 1997. Bacterial standing stock and production and their relation 
to phytoplankton in the Southern Ocean. Deep-Sea Research 44, 321-340.

Marin, V., 1987. The oceanographic structure of the eastern Scotia Sea-4. Distribution of copepod species in relation to hydrography in 1981. Deep-Sea Research 34, 105-121.

Marin, V., 1988. Qualitative models of the life cycles of Calanoides acutus, Calanus propinquus and Rhincalanus gigas. Polar Biology 8, 439-446.

Maslennikov, V.V., Solyankin, E.V., 1993. Oceanic fronts in the Southern Ocean as the main locations of myctophid and krill aggregations. Antarctika-Antarctic 32, 86-93 in Russian.

Metz, C., 1995. Seasonal variation in the distribution and abundance of Oithona and Oncaea species (Copepoda, Crustacea) in the southeastern Weddell Sea, Antarctica. Polar Biology 15, 187-194.

Metz, C., 1996. Life strategies of dominant Antarctic Oithonidae (Cyclopoida, Copepoda) and Oncaeidae (Poecilostomatoida, Copepoda) in the Bellingshausen Sea. Berichte zur Polarforschung 207, 1-123.

Nielsen, T.G., Richardson, K., 1989. Food chain structure of the North Sea plankton communities: seasonal variations of the role of the microbial loop. Marine Ecology Progress Series 56, 75-87.

Park, C., Wormuth, J.H., 1993. Distribution of Antarctic zooplankton around Elephant Island during the austral summers of 1988, 1989 and 1990. Polar Biology 13, 215-225.

Pollard, R.T., Bathmann, U., Dubischar, C., Read, J.F., Lucas, M., 2002. Zooplankton distribution and behaviour in the Southern Ocean from surveys a towed Optical Plankton Counter. Deep-Sea Research II 49 (17), 3889-3915.

Razouls, C., 1994. Manuel d'identification des principales espèces de copépodes pélagiques antarctiques et subantarctiques. Annales de I'Institut Oceánographique 70, 3-204.

Read, J.F., Pollard, R.T., Bathmann, U., 2002. Physical and biological patchiness of an upper ocean transect from South Africa to the ice edge near the Greenwich Meridian. DeepSea Research 49 (17), 3889-3915.

Roff, J.C., Turner, J.T., Webber, M.K., Hopcroft, R.R., 1995. Bacterivory by tropical copepod nauplii: extent and possible significance. Aquatic Microbial Ecology 9, 165-175.

Rutgers van der Loeff, M.M., Buesseler, K., Bathmann, U.V., Hense, I., Andrews, J., 2002. Comparison of carbon and opal export rates between summer and spring bloom periods in the region of the Antarctic Polar Front, SE Atlantic. Deep Sea Research II 49 (17), 3849-3869.

Schnack-Schiel, S.B., Mizdalski, E., 1994. Seasonal variations in distribution and population structure of Microcalanus pygmaeus and Ctenocalanus citer (Copepoda, Calanoida) in the eastern Weddell Sea, Antarctica. Marine Biology 119, 357-366.

Schnack-Schiel, S.B., Hagen, W., 1995. Life-cycle strategies of Calanoides acutus, Calanus propinquus, and Metridia gerlachei (Copepoda: Calanoida) in the eastern Weddell Sea, Antarctica. ICES Journal of Marine Science 52, 541-548.
Smetacek, V., Scharek, R., Nöthig, E.-M., 1990. Seasonal and regional variation in the pelagial and its relationship to the life history cycle of krill. In: Kerry, K.R., Hempel, G. (Eds.), Antarctic Ecosystems. Ecological Change and Conservation. Springer, Heidelberg, pp. 103-114.

Smetacek, V., De Baar, H.J.W., Bathmann, U.V., Lochte, K., Rutgers Van der Loeff, M.M., 1997. Ecology and biogeochemistry of the Antarctic circumpolar current during austral spring: a summary of Southern Ocean JGOFS cruise ANT X/6 of R.V. Polarstern. Deep-Sea Research 44, $1-21$.

Smith, S.L., Schnack-Schiel, S.B., 1990. Polar Zooplankton. In: Smith Jr., W.O. (Ed.), Polar Oceanography, Part B: Chemistry, Biology and Geology. Academic Press, New York, pp. 527-597.

Strass, V.H., Fischer, H., Allen, J.T., 1997. Underway measurements of currents and acoustic backscatter by use of the VM-ADCP. In: Bathmann, U., Lucas, M., Smetacek, V. (Eds), The expeditions Antarktis XIII1/2 of the Research Vessel "POLARSTERN" in 1995/96. Berichte zur Polarforschung, 221, 30-33.

Strass, V.H., Naveira Garabato, A.C., Pollard, R.T., Fischer, H.I., Hense, I., Allen, J.T., Read, J.F., Leach, H., Smetacek, V., 2002. Mesoscale frontal dynamics: shaping the environment of primary production in the Antarctic Circumpolar Current. Deep-Sea Research II 49 (17), 3735-3769.

Swadling, K.M., Gibson, J.A.E., Ritz, D.A, Nichols, P.D., Hughes, D.E., 1997. Grazing of phytoplankton by copepods in eastern Antarctic coastal waters. Marine Biology 128, $39-48$.

Tucker, M.J., Burton, H.R., 1990. Seasonal and spatial variations in the zooplankton community of an eastern Antarctic coastal location. Polar Biology 10, 571-579.

Turner, J.T., 1994. Planktonic copepods of Boston Harbor, Massachussetts Bay and Cape Cod Bay, 1992. Hydrobiologia 292/293, 405-413.

Turner, J.T., Dagg, M.J., 1983. Vertical distributions of continental shelf zooplankton in stratified and isothermal waters. Biological Oceanography 3, 1-40.

Turner, J.T., Tester, P.A., 1992. Zooplankton feeding ecology: bacterivory by metazoan microzooplankton. Journal of Experimental Marine Biology and Ecology 160, 149-167.

van Franeker, J., van den Brink, N.W., Bathmann, U.V., Pollard, R.T., de Baar, H.J.W., Wolff, W.J., 2002. Responses of seabirds, in particular prions (Pachyptila $\mathrm{sp.)}$ to small scale processes in the Antarctic Polar Front. DeepSea Research II 49 (17), 3931-3950.

Voronina, N.M., 1968. The distribution of zooplankton in the Southern Ocean and its dependence on the circulation of water. Sarsia 34, 277-284.

Ward, P., Atkinson, A., Murray, A.W.A., Wood, A.G., Williams, R., Poulet, S.A., 1995. The summer zooplankton community at South Georgia: biomass, vertical migration and grazing. Polar Biology 15, 195-208. 
Weikert, H., John, H.-C., 1981. Experiences with a modified Bé multiple opening-closing plankton net. Journal of Plankton Research 3, 167-176.

Yamanaka, N., 1976. The distribution of some copepods (Crustacea) in the Southern Ocean and adjacent regions from $40^{\circ}$ to $81^{\circ} \mathrm{W}$ long'. Boletim de Zoologia Universidade S. Paulo 1, 161-196.
Zmijewska, M., 1988. Vertical distribution and population structure of Copepoda in a water column between King George Island and Elephant Island (BIOMASS III, October-November 1986). Polish Polar Research 9, 283304. 